\title{
Гапон В. В.
}

кандидат педагогічних наук, начальник відділу освітнього інформаційного забезпечення ДНУ «Інститут освітньої аналітики», Київ, Україна, gapon@mon.gov.ua ORCID ID: https://orcid.org/0000-0001-7521-5450

\section{Барабаш 0. A.}

заступник начальника відділу освітнього інформаційного забезпечення ДНУ «Інститут освітньої аналітики», Київ, Україна, o_barabash@mon.gov.ua ORCID ID: https://orcid.org/0000-0003-2545-0369

\section{МОНІТОРИНГ ПОКАЗНИКІВ МАТЕРІАЛЬНО-ТЕХНІЧНОГО ЗАБЕЗПЕЧЕННЯ ЗАКЛАДІВ ВИЩОЇ ОСВІТИ}

Анотація. Стаття присвячена інформаційно-аналітичним засобам обліку та аналізу матеріально-технічного забезпечення в закладах вищої освіти (ЗВо) для надання якісних освітніх послуг. У процесі дослідження розроблено методи опрацювання й аналізу галузевої інформації для формування системи аналітичних показників, що визначають ефективність використання матеріально-технічної бази на різних рівнях управління (заклади вищої освіти, Міністерство освіти і науки України, Фонд державного майна Украӥни). Створено інформаційне середовище для підготовки зведених звітів на рівні галузі освіти та їх передання до вказаного фонду з метою складання Єдиного реєстру державного нерухомого майна України. Розроблено низку аналітичних показників для оцінювання стану навчальних корпусів і гуртожитків за результатами діяльності ЗВО у 2019 р. загалом по Україні, в розрізі груп ЗВО (залежно від профілю) й кожного закладу вищої освіти. Аналіз виконано на основі таких показників, як забезпеченість площами в навчальних корпусах та гуртожитках у розрахунку на одного студента денної форми навчання, середньорічна вартість оплати комунальних послуг на утримання одного квадратного метра площі будівель, коефіцієнт їх зносу, вікова структура будівель, протипожежна безпека, аварійність будівель, що уможливлює виявлення технічно застарілих об'єктів, котрі потребують ремонту, модернізації або виведення з експлуатації.

Ключові слова: заклади вищої освіти, моніторинг, матеріально-технічна база, аналітичні показники, державне нерухоме майно, навчальні корпуси, гуртожитки.

JEL classification: I21, I23, Y10.

DOI: $10.32987 / 2617-8532-2021-1-39-54$.

Основними завданнями у сфері матеріально-технічного забезпечення закладів вищої освіти (ЗВ0) передбачено впорядкування функціонування навчально-лабораторних корпусів, гуртожитків, санаторіїв-профілакторіїв, забезпечення будівництва та реконструкції приміщень, їх своєчасного ремонту, створення матеріаль-

(C) Гапон В. В., Барабаш О. А., 2021 но-технічних і санітарно-гігієнічних умов для організації навчальновиховного процесу. При цьому Міністерство освіти і науки України (МOH) здійснює контроль та аналіз ефективності використання і збереження закріпленого за 3ВО майна.

Аналіз наукових джерел свідчить про різноманіття підходів до аналізу 
структурних компонентів матеріально-технічного забезпечення, розроблення методів та системи показників, за допомогою яких здійснюється оцінювання. Зокрема, науковці В. В. Стадник [1; 2], А. Йохна [1; 3], Г. О. Соколюк [2] зосереджуються на формуванні системи збалансованих показників, що мають орієнтувати на структурування цілей у досліджуваній сфері та використовуватись як основа для вимірювання ефективності діяльності й досягнутих результатів. Структурування цілей, на їхню думку, повинне починатися із фінансових показників, котрі відображають загальні фінансові результати, та доповнюватися нефінансовими показниками. На переконання науковців, уведення саме цих показників дає змогу підвищити оперативність управління за умови існування безпосереднього зв'язку між ними й можливістю досягнення результатів.

О. В. Ярмош [4] до ключових індикаторів ефективності використання майна зараховує співвідношення загального доходу від квадратного метра приміщень, сумарної вартості майна від загального доходу 3В0; капіталовкладень і технічного обслуговування від вартості нерухомості, вартість комунальних послуг, технічного обслуговування й витрат на обслуговування одного квадратного метра площ.

Доцільно наголосити, що в багатьох публікаціях розглядаються проблеми забезпечення практичної реалізації випереджального оновлення матеріально-технічної бази, якісних перетворень обслуговуючої інфраструктури. Також підкреслюється необхідність розроблення системи кількісних, якісних і розрахункових показників оцінювання ефективності використання матеріально-технічної бази. До них можна віднести чисельність навчально-лабораторних корпусів, гуртожитків, їдалень, їх вартість та площу. Такі явища, як брак площ навчальних корпусів, їх технічне старіння, негативно позначаються на доступності та якості освіти, збереженні здоров'я її здобувачів.

Високо оцінюючи внесок вітчизняних авторів у вирішення методико-теоретичних питань аналізу матеріально-технічного забезпечення, варто звернути увагу на об'єктивну потребу в дослідженні його практичного застосування та проведенні порівняння серед 3 В0 з урахуванням використання бюджетних і власних коштів.

Метою статті є здійснення порівняльного аналізу стану матеріально-технічного забезпечення закладів вищої освіти МОН на базі окреслених статистичних і фінансових показників. Головними завданнями є: дослідження інформаційних потоків, що забезпечують ефективність використання матеріально-технічної бази, розроблення методів і підходів для моніторингу нерухомого майна, визначення основних потреб користувачів інформаційної системи на різних рівнях управління. У процесі підготовки статті застосовано загальнонаукові й спеціальні методи дослідження, зокрема системного аналізу i структурно-ієрархічний, за допомогою яких розроблено інформаційну модель системи управління матеріально-технічним забезпеченням; порівняльно-зіставний та системно-структурний, за допомогою котрих розкрито зміст 
та структуру форм звітності; метод статистичного визначення зв'язків і залежностей між показниками, за допомогою якого сформовано основні групи показників, схеми розрахунку аналітичних індикаторів, побудовано електронні статистичні таблиці; графічні методи відображення інформаційно-аналітичних даних.

Головним завданням держави $\epsilon$ поліпшення якості й конкурентоспроможності вищої освіти в нових економічних умовах, прискорення інтеграції України в міжнародний освітній простір. Відповідно до ст. 70 Закону України «Про вищу освіту», матеріально-технічна база ЗВО відіграє велику роль у створенні необхідних умов для навчання та якісної підготовки фахівців з вищою освітою та включає в себе будівлі, споруди, комунікації, обладнання, транспортні засоби, службове житло, землю та інше майно [5].

Згідно з постановами Кабінету Міністрів України від 14.04.2004 № 467 «Про затвердження Положення про Єдиний реєстр об'єктів державної власності» [6] та від 30.11.2005 № 1121 «Про затвердження Методики проведення інвентаризації об'єктів державної власності» [7], наказом Міністерства освіти і науки України від 19.01.2009 № 23 [8], заклади вищої освіти подають до МОН звіт за формою 2б(д) «Відомості про державне майно (нерухоме майно державних підприємств, їх об'єднань, установ та організацій)».

Технологія збору та опрацювання інформації передбачає складання електронних звітів із використанням програмного забезпечення Фонду державного майна України (ФДМУ) на всіх рівнях управління (навчальні заклади та установи освіти й науки, обласні департаменти / управління освіти і науки, МОН, ФДМУ). База даних (БД) «Юридичні особи» на дату інвентаризації основних фондів містить:

- відомості про юридичну особу / балансоутримувача державного майна (ідентифікаційний код за ЄДРПОУ, повне найменування, місцезнаходження, загальний розмір земельної ділянки);

- відомості про державне майно (реєстровий номер майна, код та назва майна відповідно до класифікатора державного майна, інвентарний номер майна, назва та місцезнаходження майна, вартість майна на дату останньої інвентаризації (первісна, залишкова та експертна), дата останньої індексації основних фондів, розмір земельної ділянки / площа забудови, розмір/площа об’єкта);

- відомості про державну реєстрацію на право власності;

- зведені дані щодо державного майна.

Для аналізу функціонування й управління матеріально-технічним забезпеченням розроблено схему інформаційних потоків, що забезпечує взаємозв'язок передання звітної інформації між органами управління в галузі освіти (рис. 1).

Для аналізу фінансових показників ефективності використання матеріально-технічної бази використано звітність про фінансово-господарську діяльність ЗВО за 2019 р., яка подається відповідно до Порядку складання бюджетної звітності розпорядниками та одержувачами бюджетних коштів, звітності фондів загальнообов'язкового державного соціального й пенсійного страхування 


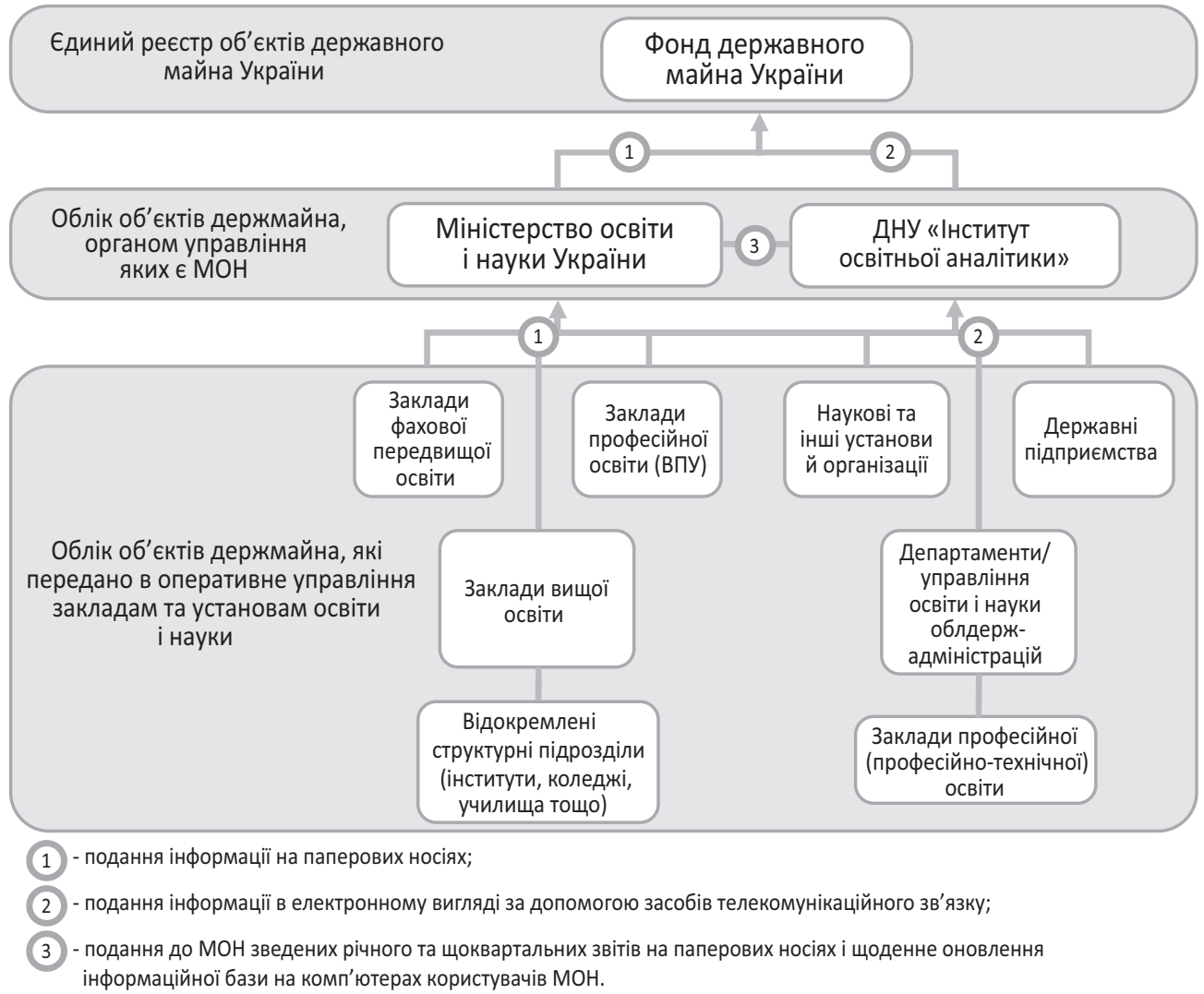

\section{Рис. 1. Схема інформаційних потоків передання звітної інформації системи матеріально-технічного забезпечення галузі освіти}

Побудовано авторами.

та інших нормативно-правових і законодавчих актів з бухгалтерського обліку в державному секторі [9-11].

Фінансування діяльності 3 В0 здійснюється за рахунок бюджетних коштів, коштів юридичних і фізичних осіб та доходів від основної й допоміжної господарської діяльності установи за бюджетними програмами КПКВ 2201160 «Підготовка кадрів вищими навчальними закладами III-IV рівнів акредитації та забезпечення діяльності їх баз практики» $\mathrm{i}$ КПКВ 2201280 «Підготовка кадрів Київським національним університетом імені Тараса Шевченка».
Фінансові ресурси спрямовуються як на підготовку фахівців, що навчаються у 3В0, так і на належне утримання матеріально-технічної бази цих закладів, модернізацію, ремонт будівель та споруд, котрі перебувають на їх балансі.

У дослідженні для аналізу показників матеріально-технічного забезпечення ЗВО використано інформацію, що відображена в таких формах звітності:

- форма 2б(д) «Відомості про державне майно (нерухоме майно державних підприємств, їх об'єднань, установ та організацій)»; 
- форма 2д «Звіт про надходження та використання коштів загального фонду»;

- форма 4-1д «Звіт про надходження і використання коштів, отриманих як плата за послуги»;

- форма 4-2д «Звіт про надходження і використання коштів, отриманих за іншими джерелами власних надходжень»;

- форма 3-2 «Звіт про виконання плану по штатах і контингентах закладів підготовки і підвищення кваліфікації кадрів».
Схема формування аналітичних показників для оцінювання ефективності використання матеріально-технічного забезпечення 3ВО наведена на рис. 2.

За основу для вимірювання й моніторингу ефективності використання матеріально-технічного забезпечення ЗВО взято низку кількісних, вартісних, якісних та розрахункових показників, котрі в комплексі дають змогу приймати оптимальні управлінські рішення. При цьому розроблення системи показників ґрунту-

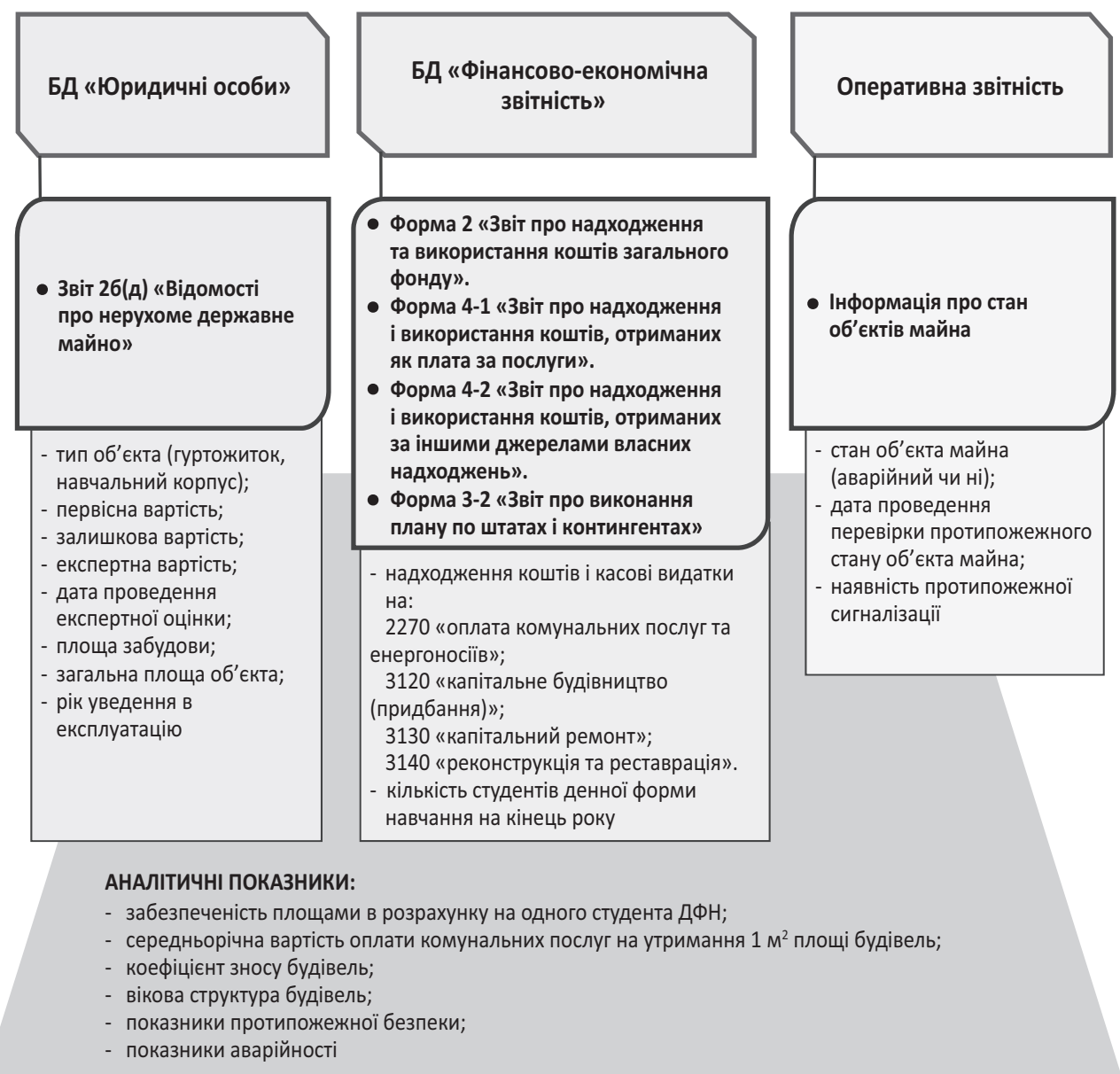

Рис. 2. Схема формування аналітичних показників для оцінювання ефективності використання матеріально-технічного забезпечення 3 В0

Побудовано авторами. 
ється на виокремленні такої їх оптимальної сукупності, що відображає результативність підготовки фахівців із вищою освітою.

Кількісні показники матеріально-технічної бази характеризують наявність об’єктів, їх площу й вартість, а якісні - відповідність елементів вимогам державних освітніх стандартів, навчальним планам i програмам, вимогам охорони праці й техніки безпеки, зокрема протипожежної, санітарним умовам тощо. Вікова структура основних засобів і знос елементів матеріально-технічної бази уможливлюють виявлення технічно застарілих об’єктів, які потребують ремонту, модернізації або виведення з експлуатації.

До розрахункових показників віднесено: забезпеченість площами в навчальних корпусах і гуртожитках на одного студента денної форми навчання (ДФН), середньорічну вартість оплати комунальних послуг на утримання одного квадратного метра площі будівель, коефіцієнт їх зносу.

Аналіз показників використання матеріально-технічної бази проведено в розрізі груп ЗВО (залежно від профілю), таких як класичні університети; технічні; технологічні, будівництва та транспорту; педагогічні, гуманітарні, фізичного виховання i спорту, мистецтва та дизайну; права, економіки, управління, підприємництва й торгівлі; аграрні.

У дослідженні зазначений аналіз розпочато зі сфери фінансових показників 3В0, котрі відображають загальні фінансові результати діяльності. Згідно із фінансовою звітністю університетів за 2019 р., надходження коштів, отриманих як плата за послуги (форма 4-1д), становлять 10354 млн грн, у т. ч. за послуги, що надаються бюджетними установами за їх основною діяльністю, 8051 млн грн (77,8 \%); доходи від додаткової господарської діяльності 2185 млн грн (21,1 \%), від оренди майна - 95,8 млн грн (0,93 \%), від реалізації в установленому порядку майна (крім нерухомого) - 21,9 млн грн $(0,21 \%)$.

Надходження коштів, отриманих за іншими джерелами власних надходжень (форма 4-2д), дорівнюють 604,4 млн грн, із них від благодійних внесків, грантів і дарунків 380,5 млн грн (62,9 \%); від підприємств, організацій, фізичних осіб для виконання цільових заходів 37,9 млн грн (6,3 \%); від розміщення на депозитах тимчасово вільних бюджетних коштів, одержаних за надання платних послуг, проценти, нараховані на залишок коштів, та ін. - 186,1 млн грн (30,8 \%).

Технічний стан нерухомого майна впливає на визначення показників фінансування для його утримання в належному стані, забезпечення безперебійного функціонування різноманітних комунікацій та необхідного санітарного й протипожежного режиму. Тому в умовах ринкових відносин від ЗВО вимагається ефективно використовувати матеріально-технічне забезпечення в навчальному процесі.

Проведений аналіз свідчить, що найбільшу сумарну площу навчальних корпусів мають три столичних 3BO, а саме: Національний технічний університет України «Київський політехнічний інститут імені Ігоря Сікорського» - 333,6 тис. м $^{2}$ та 35 корпусів, Національний авіа- 
ційний університет - 253,5 тис. м $^{2} \mathrm{i}$ 75 корпусів, Київський національний університет імені Тараса Шевченка - 232,2 тис. м² та 71 корпус. Далі за ранжуванням ідуть Національний університет «Львівська політехніка» - 227,4 тис. м² і 57 корпусів, Національний університет біоресурсів і природокористування України 198,7 тис. м² та 71 корпус. Усі ці ЗВО розташовані в містах обласного підпорядкування із чисельністю населення понад 600 тис. осіб.

Також встановлено, що 60 \% 3В0 мають на балансі мінімум чотири навчальних корпуси й тільки 33 \% по одному. В аграрних університетів більша кількість таких корпусів, але за розміром останні значно менші.

Найбільші навчальні корпуси належать Дніпровському національному університету залізничного транспорту імені академіка В. Лазаряна $\left(35,4\right.$ тис. $\left.\mathbf{m}^{2}\right)$, Національному технічному університету України «Ки- ївський політехнічний інститут імені Ігоря Сікорського» (32,3 тис. м $^{2}$, Київському національному університету імені Тараса Шевченка (29,6 тис. м $\left.^{2}\right)$, Київському національному університету технологій та дизайну $\left(27,9\right.$ тис. м $\left.^{2}\right)$, Одеському національному політехнічному університету $\left(24,7\right.$ тис. $\left.\mathbf{m}^{2}\right)$.

Для порівняльного аналізу оптимальності використання навчальних корпусів і гуртожитків 3 ВО використано показник забезпеченості площами в розрахунку на одного студента ДФН у розрізі груп ЗВО за 2019 р. (рис. 3).

Серед основних груп 3 ВО найбільшу середню площу в розрахунку на одного студента ДФН мали навчальні корпуси аграрних університетів - 18,77 м², котра перевищувала середню по Україні на 44,2 \%. Також більшим 32,7 \% від середнього значення по країні цей показник був у технологічних закладах, будівництва

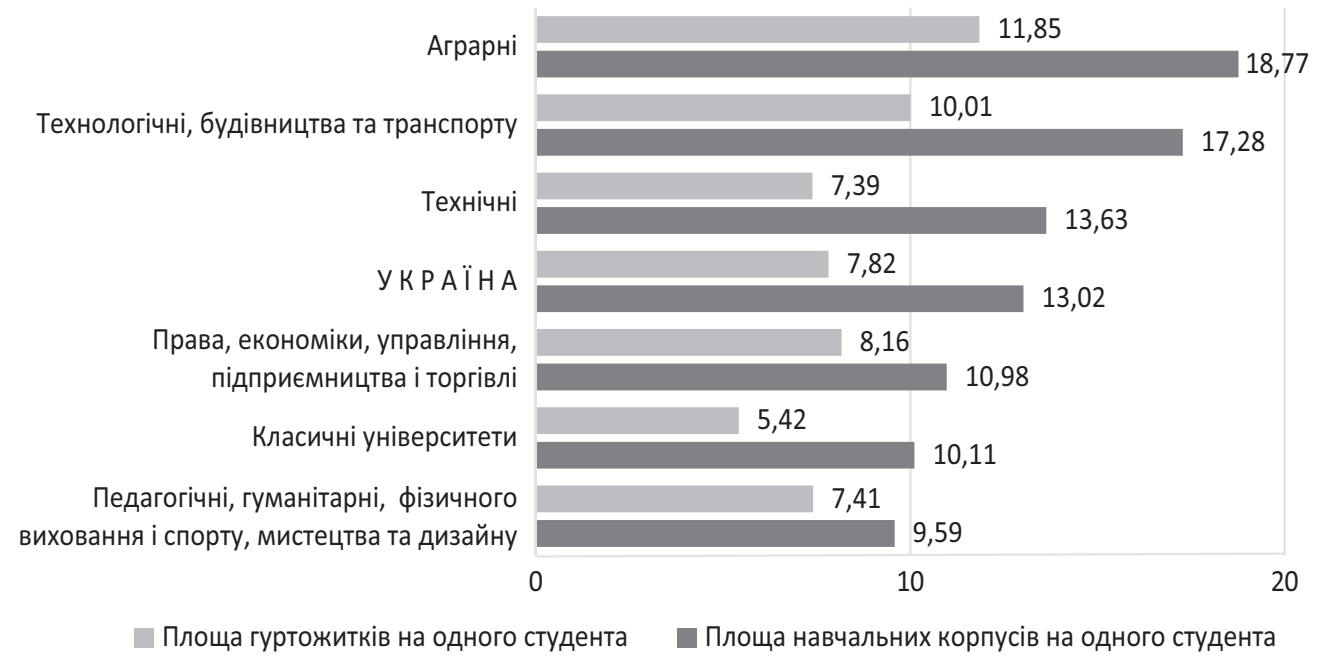

Рис. 3. Забезпеченість площами в розрахунку на одного студента денної форми навчання в навчальних корпусах і гуртожитках за групами 3B0, $\mathrm{M}^{2}$

Побудовано авторами на основі БД «Юридичні особи» та БД «Фінансово-економічна звітність» за 2019 р. 


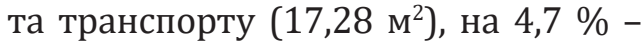

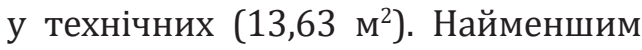
значення середньої площі $\epsilon$ в педагогічних, гуманітарних університетах, а також фізичного виховання і спорту, мистецтва та дизайну - 9,59 м² (на 26,4 \% нижче від середнього показника по Україні).

Серед 3 ВО найбільша площа на одного студента ДФН у навчальних корпусах зафіксована в Криворізькому національному університе-

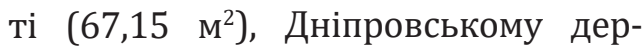
жавному технічному університеті $\left(59,59\right.$ м $\left.^{2}\right)$, Подільському державному аграрно-технічному університеті (46,62 м²), Львівському національному аграрному університеті $(40,81$ м²), Українському державному хіміко-технологічному університеті $\left(36,28\right.$ м $\left.^{2}\right)$, Одеському державному аграрному університеті $\left(35,83 \mathrm{~m}^{2}\right)$; найменша - в Рівненському державному гуманітарному університеті $\left(5,18\right.$ м $\left.^{2}\right)$, Переяслав-Хмельницькому державному педагогічному університеті імені Григорія Сковороди $\left(5,37 \mathrm{~m}^{2}\right)$, Київському лінгвістичному університеті (5,8 м²), Уманському державному педагогічному університеті імені Павла Тичини (5,9 м²).

Велике соціальне значення для ЗВО має наявність гуртожитків, кількість у них місць для проживання, забезпеченість студентів місцями, належний протипожежний і санітарногігієнічний стан.

Порівняльний аналіз забезпеченості площами в гуртожитках дав можливість виявити групи 3В0, де цей показник $є$ найкращим. Це група аграрних університетів - 11,85 м² (на 51,2 \% вище за середнє значення по Україні); технологічних закладів, будівництва та транспорту - 10,1 м²
(28 \%); права, економіки, управління, підприємництва і торгівлі - 8,16 м² $(4,3$ \%). Найменшим цей показник був у групі класичних університетів - 5,42 м², що на $31 \%$ нижче від середнього значення по країні.

Серед ЗВО найбільша площа на одного студента ДФН у навчальних корпусах зафіксована в Луганському національному аграрному університеті (27 $\left.\mathrm{m}^{2}\right)$, Дніпровському державному технічному університеті

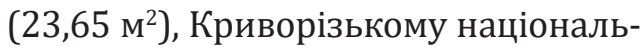

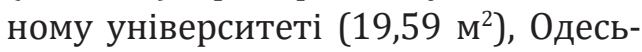
кій державній академії технічного регулювання та якості $\left(17,35 \mathrm{~m}^{2}\right)$, Ніжинському державному університеті імені Миколи Гоголя (14,91 м²); найменша - в Уманському державному педагогічному університеті імені Павла Тичини $\left(2,59 \mathrm{~m}^{2}\right)$, Луганському національному університеті імені Та-

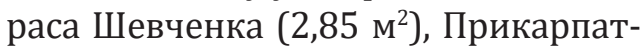
ському національному університеті імені Василя Стефаника (2,95 м²), Державному університеті телекому-

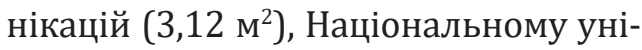
верситеті «Києво-Могилянська ака-

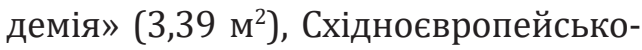
му національному університеті імені

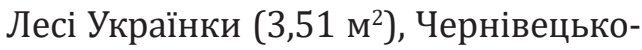
му національному університеті імені Юрія Федьковича $\left(3,81 \mathrm{~m}^{2}\right)$.

За результатами дослідження найбільшу загальну площу гуртожитків мають чотири столичних 3ВО. Це Національний університет біоресурсів і природокористування України 162,7 тис. м² і 50 гуртожитків, Київський національний університет імені Тараса Шевченка - 158,1 тис. м $^{2}$ та 31 гуртожиток, Національний авіаційний університет - 157,2 тис. м $^{2}$ i 38 гуртожитків, Національний технічний університет України «Київ- 
ський політехнічний інститут імені Ігоря Сікорського» - 148,5 тис. м $^{2}$ та 21 гуртожиток. Далі йдуть Національний університет «Львівська політехніка» - 145,6 тис. м² і 25 гуртожитків, Національний технічний університет «Харківський політехнічний інститут» - 114,6 тис. $\mathrm{M}^{2}$ та 15 гуртожитків.

Визначено найбільші за площею будівлі гуртожитків. Вони належать Національному технічному університету «Харківський політехнічний інститут» - 27,5 тис. м², Українському державному університету залізничного транспорту - 17,9 тис. м $^{2}$, Національному університету кораблебудування імені адмірала Макарова 16,4 тис. м $^{2}$, Національному технічному університету України «Київський політехнічний інститут імені Ігоря Сікорського» - 15 тис. м², Харківському національному педагогічному університету імені Г. С. Сковороди 15 тис. $\mathrm{M}^{2}$.

За рахунок коштів загального і спеціального фондів здійснюється оплата на утримання будівель за надані комунальні послуги та енергоносії, включаючи оплату тепло-, водопо- стачання й водовідведення, електроенергії, природного газу, інших енергоносіїв. У цілому по Україні касові видатки на оплату комунальних послуг на утримання будівель ЗВО у 2019 р. сягають 2 298,4 млн грн, у т. ч. із загального фонду - 1382,8 млн грн, спеціального - 915,6 млн грн (табл. 1).

Як свідчать наведені дані, частка касових видатків загального фонду на оплату комунальних послуг, вища від середнього значення по Україні, характерна для таких груп 3ВО, як технологічні, будівництва та транспорту (62,9 \%) і права, економіки, управління, підприємництва й торгівлі $(65,1 \%)$.

У дослідженні виконано аналіз середньорічної вартості оплати комунальних послуг на утримання будівель у розрахунку на 1 м² площі будівель (рис. 4). Очевидно, що найвищим цей показник $\epsilon$ в групі педагогічних, гуманітарних 3В0, фізичного виховання і спорту, мистецтва та дизайну - 215,87 грн (на 18 \% більше за середній по Україні), а найнижчим - у аграрній групі 130,87 грн (на 28,3 \% менше від середнього значення).

Таблиця 1

Касові видатки на оплату комунальних послуг 3В0 за 2019 р.

\begin{tabular}{|c|c|c|c|c|}
\hline \multirow[b]{2}{*}{ Групи Зво } & \multicolumn{3}{|c|}{ Касові видатки, млн грн } & \multirow{2}{*}{$\begin{array}{c}\text { Частка } \\
\text { загального } \\
\text { фонду, \% }\end{array}$} \\
\hline & $\begin{array}{c}\text { Загальний } \\
\text { фонд }\end{array}$ & $\begin{array}{c}\text { Спеціальний } \\
\text { фонд }\end{array}$ & Разом & \\
\hline Класичні університети & 306,6 & 224,1 & 530,7 & 57,8 \\
\hline Технічні & 339,3 & 230,7 & 570,0 & 59,5 \\
\hline Технологічні, будівництва та транспорту & 298,9 & 176,6 & 475,5 & 62,9 \\
\hline $\begin{array}{l}\text { Педагогічні, гуманітарні, фізичного } \\
\text { виховання і спорту, мистецтва та дизайну }\end{array}$ & 151,3 & 109,2 & 260,5 & 58,1 \\
\hline $\begin{array}{l}\text { Права, економіки, управління, } \\
\text { підприємництва і торгівлі }\end{array}$ & 135,1 & 72,5 & 207,6 & 65,1 \\
\hline Аграрні & 151,6 & 102,5 & 254,1 & 59,6 \\
\hline Всього & 1382,8 & 915,6 & 2298,4 & 60,2 \\
\hline
\end{tabular}

Складено авторами на основі БД «Фінансово-економічна звітність» за 2019 р. 
Педагогічні, гуманітарні, фізичного виховання і спорту, мистецтва та дизайну

Класичні університети

Технічні

УК

$$
\text { YKPAÏHA }
$$

Права, економіки, управління, підприємництва і торгівлі

Аграрні

\section{Рис. 4. Середньорічна вартість оплати комунальних послуг у розрахунку на 1 м² $^{2}$} площі навчальних корпусів та гуртожитків за групами 3В0, грн

Побудовано авторами на основі БД «Юридичні особи» та БД «Фінансово-економічна звітність» за 2019 р.

Найбільшою вартість оплати комунальних послуг у розрахунку на

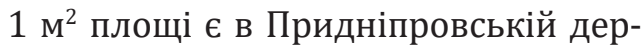
жавній академії фізичної культури і спорту (458,31 грн), Львівському національному університеті імені Івана Франка (394,56 грн), Одеському національному політехнічному університеті (392,67 грн), Київському національному лінгвістичному університеті $(315,16$ грн), Харківському національному університеті радіоелектроніки $(304,44$ грн), Національному університеті «Острозька академія» (284,7 грн); найменшою - в Донецькому національному університеті економіки і торгівлі імені Михайла Туган-Барановського (28,78 грн), Криворізькому національному університеті (43,06 грн), Таврійському державному агротехнологічному університеті імені Дмитра Моторного (56,76 грн), Львівському національному університеті ветеринарної медицини та біотехнологій імені С. 3. Гжицького (65,51 грн), Донецькому національному технічному університеті
(76,28 грн), Подільському державному аграрно-технічному університеті (80,91 грн), Мукачівському державному університеті (84,83 грн).

Аналіз стану будівель навчальних корпусів і гуртожитків проведено за таким показником як коефіцієнт зносу елементів матеріально-технічної бази, котрий обраховується як відношення залишкової вартості об'єкта до його первісної вартості (у відсотках) та представлено за групами $3 В 0$ на рис. 5.

Наведені дані свідчать, що найменший середній показник зносу навчальних корпусів характерний для 3ВО права, економіки, управління, підприємництва й торгівлі (32,65 \%); в усіх інших групах він удвічі більший та варіює від 62,31 \% (аграрні) до 74,13 \% (технічні).

За допомогою аналізу виявлено 38 закладів (27 \% загальної кількості 3В0), що мають на балансі застарілі навчальні корпуси із середнім коефіцієнтом зносу понад 90 \%. Це Дніпровський національний університет імені Олеся Гончара, Хар- 


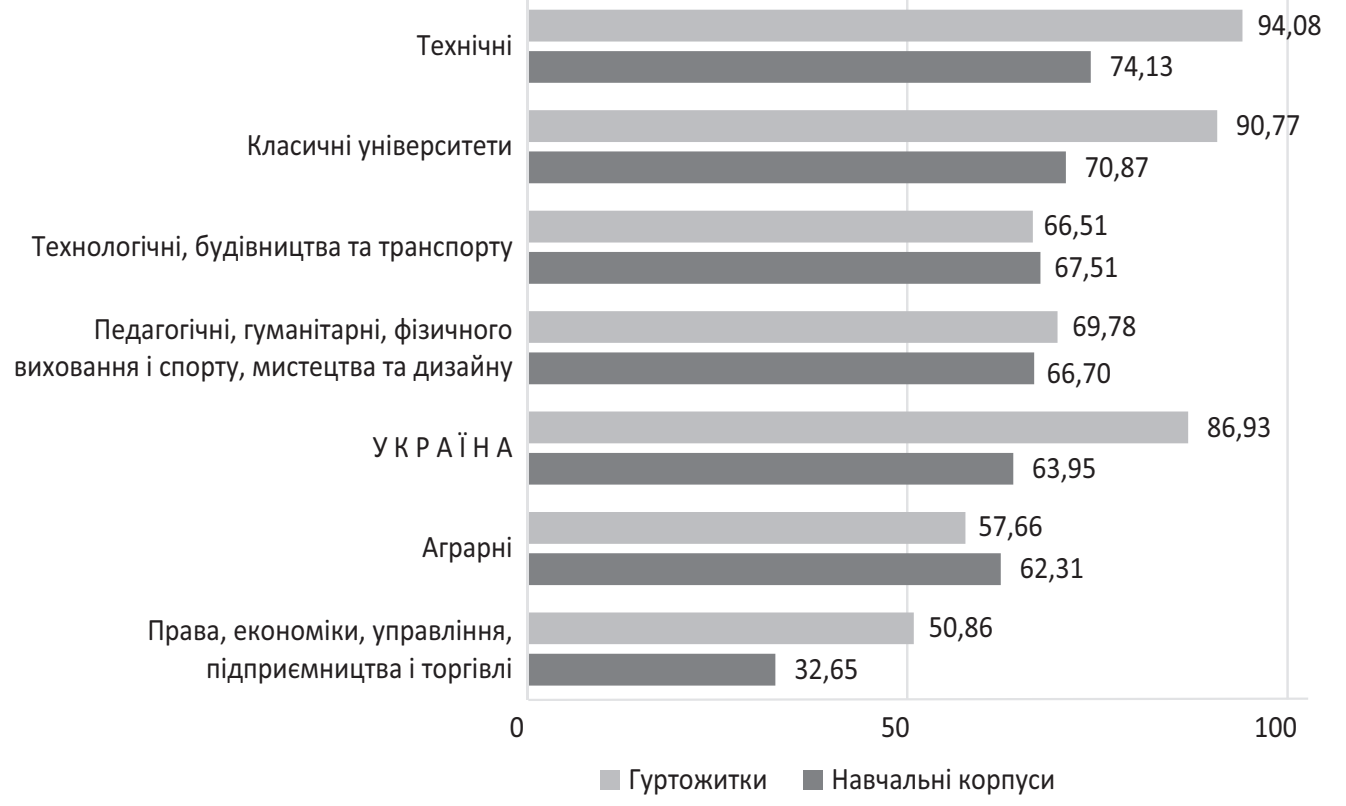

Рис. 5. Середні коефіцієнти зносу навчальних корпусів та гуртожитків за групами 3В0, \%

Побудовано авторами на основі БД «Юридичні особи».

ківський національний університет імені В. Н. Каразіна, Тернопільський національний педагогічний університет імені Володимира Гнатюка, Дрогобицький державний педагогічний університет імені Івана Франка, Центральноукраїнський державний педагогічний університет імені Володимира Винниченка, Одеський національний морський університет, Українська академія друкарства.

У 363 В0 (25,7 \% загальної кількості) середній коефіцієнт зносу навчальних корпусів становить до 50 \%, найменші його значення спостерігаються у Вінницькому державному педагогічному університеті імені Михайла Коцюбинського (9,6 \%), Одеському національному економічному університеті (11,8 \%), Одеській державній академії будівництва та архітектури (11,9 \%), Ужгородському національному університеті
(14,8 \%), Харківському національному технічному університеті сільського господарства імені Петра Василенка (16,3%), Чернівецькому національному університеті імені Юрія Федьковича $(18,1$ \%), Мукачівському державному університеті (26,9%).

Найбільш застарілі об’єкти гуртожитків належать 3В0, які входять до груп класичних університетів i технічних, та становлять відповідно 90,77 і 94,08 \%. Найнижчим цей показник є у ЗВО права, економіки, управління, підприємництва й торгівлі (50,86 \%).

Детальний аналіз дав можливість виявити $3 \mathrm{BO} 3$ найвищим середнім коефіцієнтом зносу будівель гуртожитків. Так, 100 \% зносу мають будівлі гуртожитків Національного аерокосмічного університету імені М. Є. Жуковського «Харківський авіаційний інститут», Донецького націо- 
нального університету економіки і торгівлі імені Михайла Туган-Барановського, Бердянського державного педагогічного університету, Київського національного лінгвістичного університету, Харківського національного педагогічного університету імені Г. С. Сковороди, Одеського національного економічного університету, Луганського національного аграрного університету, Миколаївського національного аграрного університету. Найменш зношеними є будівлі гуртожитків Східноєвропейського національного університету імені Лесі Українки (9,13 \%), Харківського національного університету міського господарства імені О. М. Бекетова $(10,8 \%)$, Львівського національного аграрного університету $(18,4$ \%), Національного юридичного університету імені Ярослава Мудрого (19,9\%), Одеської державної академії будівництва та архітектури (20,7 \%), Університету банківської справи $(24,7 \%)$, Національного університету «Запорізька політехніка» (28,8 \%), Ізмаїльського державного гуманітарного університету (31,0 \%), Національного університету фізичного виховання і спорту України $(34,7$ \%)

У процесі дослідження здійснено пооб'єктний аналіз розподілу навчальних корпусів і гуртожитків за коефіцієнтом зносу (рис. 6). Як свідчать наведені дані, коефіцієнт зносу до 50 \% мають 402 навчальних корпуси (або 17,8 \%) та 215 гуртожитків (22 \%); 50-75 \% - 298 од. (13,2 \%) навчальних корпусів і 182 од. (18,6 \%) гуртожитків. При цьому для найбільшої кількості навчальних корпусів (1557 од., або 69 \%) та гуртожитків (580 од., або 59,4 \%) такий коефіцієнт дорівнює понад 75 \%.
На 100 \% зношені будівлі 902 навчальних корпусів, тобто 40 \% їх загальної чисельності. 3 них у групі класичних університетів - 175 од. (19,4 \% кількості навчальних корпусів зі 100-відсотковим зносом); технічних - 199 од. (22,1 \%); технологічних, будівництва та транспорту - 170 од. (18,9 \%); педагогічних, гуманітарних, фізичного виховання і спорту, мистецтва та дизайну 104 од. (11,5 \%); права, економіки, управління, підприємництва і торгівлі - 39 од. (4,3 \%); аграрних - 215 од. $(23,8 \%)$.

Також на $100 \%$ зношені будівлі 216 гуртожитків, тобто $22 \%$ їх загальної чисельності. 3 них у групі класичних університетів - 26 од. $(12,1 \%$ кількості гуртожитків зі 100-відсотковим зносом); технічних - 51 од. (23,6 \%); технологічних, будівництва та транспорту - 42 од. $(19,4$ \%); педагогічних, гуманітарних, фізичного виховання і спорту, мистецтва та дизайну - 27 од. (12,5 \%); права, економіки, управління, підприємництва й торгівлі - 11 од. (5,1\%); аграрних - 59 од. (27,3 \%).

Згідно з БД «Юридичні особи», перші будівлі навчальних корпусів ЗВО введено в експлуатацію в 1646 р. (педагогічна група 3В0), а гуртожитків - у 1830 р. (аграрна група 3В0).

За оперативними даними, отриманими від $3 \mathrm{BO}$ (лист МОН від 11.12.2019 № 1/9-755), проведено аналіз стану протипожежної безпеки та аварійного стану будівель. Згідно 3 його результатами, протипожежну сигналізацію встановлено в 763 гуртожитках, що становить 78,1 \% їх загальної кількості, й у 234 навчальних корпусах, або 10,4 \%. Інформацію про виконані перевірки стану протипо- 


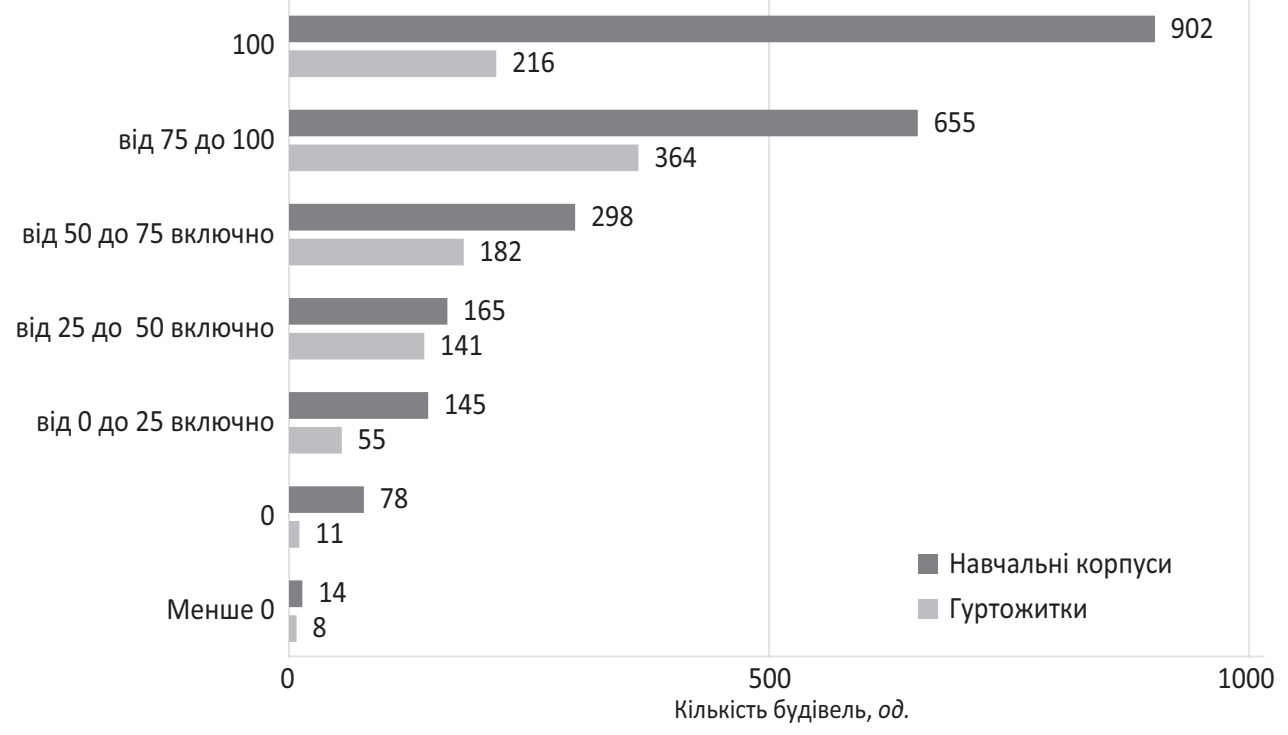

Рис. 6. Розподіл навчальних корпусів і гуртожитків ЗВ0 за коефіцієнтом зносу, \% Побудовано авторами на основі БД «Юридичні особи».

жежної безпеки в навчальних корпусах і гуртожитках наведено в табл. 2 . Як бачимо, ретельні перевірки протипожежного стану в університетах проводились упродовж останніх двох років.

На 01.12.2020 в аварійному стані перебуває 381 будівля, котра значиться на балансі 3В0, в тому числі 46 гуртожитків $(12,1 \%)$ і 57 навчальних корпусів (15\%).

Чимала частина аварійних будівель перебуває на балансі ЗВО аграрної групи, а саме Луганського національного аграрного університету (7 гуртожитків, 2 корпуси), Дніпровського державного аграрно- економічного університету (5 гуртожитків, 2 навчальних корпуси), Вінницького національного аграрного університету (2 гуртожитки, 1 навчальний корпус), Білоцерківського національного аграрного університету (3 гуртожитки, 3 навчальних корпуси), Львівського національного аграрного університету (1 гуртожиток, 8 корпусів), Таврійського державного агротехнологічного університету імені Дмитра Моторного (2 гуртожитки, 4 корпуси).

Серед інших профільних груп 3ВО аварійний стан мають гуртожитки й навчальні корпуси Луганського національного університету імені Тараса

\section{Будівлі ЗВ0, охоплені перевіркою протипожежного стану, за роками, \%}

\begin{tabular}{|l|c|c|c|c|c|c|}
\hline \multicolumn{1}{|c|}{ Тип будівлі } & $\mathbf{2 0 0 9 - 2 0 1 4}$ & $\mathbf{2 0 1 5}$ & $\mathbf{2 0 1 6}$ & $\mathbf{2 0 1 7}$ & $\mathbf{2 0 1 8}$ & $\mathbf{2 0 1 9}$ \\
\hline Навчальні корпуси & 2,8 & 1,5 & 3,7 & 4,8 & 10,1 & 77,1 \\
\hline Гуртожитки & 2,0 & 0,7 & 4,5 & 7,6 & 10,9 & 74,3 \\
\hline
\end{tabular}

Складено авторами на основі оперативної інформації, отриманої від ЗВО (лист МОН від 11.12.2019 № 1/9-755). 
Шевченка (2 гуртожитки, 2 корпуси), Львівської національної академії мистецтв (1 гуртожиток, 3 корпуси), Львівського державного університету фізичної культури імені Івана Боберського (1 гуртожиток, 3 корпуси). По два аварійних гуртожитки в Національного університету «Одеська юридична академія» та Одеського державного екологічного університету.

Отже, вікова структура об’єктів матеріально-технічної бази й коефіцієнт зносу дають змогу виявити технічно застарілі об'єкти, що потребують ремонту, модернізації або виведення 3 експлуатації. Здійснені заходи з перевірки протипожежної безпеки вказу- ють на необхідність встановлення в навчальних корпусах 3 В0 додаткової протипожежної сигналізації.

Запропоновані аналітичні показники оптимальності використання площ у навчальних корпусах і гуртожитках університетів уможливлюють проведення порівняльного аналізу ефективності спрямування фінансових ресурсів на утримання цих будівель.

Предметом подальших досліджень має бути розроблення інформаційно-аналітичної системи, яка забезпечить поєднання й застосування показників двох баз даних, а саме «Юридичні особи» та «Фінансовоекономічна звітність».

\section{Список використаних джерел}

1. Стадник В. В., Йохна А. Стратегічне управління інноваційним розвитком підприємства. Хмельницький : ХНУ, 2011. 327 с.

2. Стадник В. В., Соколюк Г. О. Використання збалансованої системи показників для реалізації диверсифікованого зростання. Вісник Хмельницького національного універcumemy. 2012. № 4. T. 2. С. 125-131.

3. Концепції інституціональної економічної теорії в управлінні розвитком соціально-економічних систем : монографія / за заг. ред. М. А. Йохни. Хмельницький : ХНУ, 2007. 313 c.

4. Ярмош О. В. Система показників моніторингу стратегії розвитку вищих навчальних закладів. Актуальні питання підвищення конкурентоспроможності держави, бізнесу та освіти в сучасних економічних умовах : матеріали I Міжнар. наук.-практ. конф., м. Полтава, 14-15 лют. 2013 р. Дніпропетровськ : Біла К. О., 2013. С. 100-102. URL: http://www.confcontact.com/20130214_econ/2013_02_14_econ_tom2.pdf.

5. Про вищу освіту : закон України від 01.07.2014 № 1556-VII. URL: http://zakon4. rada.gov.ua/laws/show/1556-18/page.

6. Про затвердження Положення про Єдиний реєстр об'єктів державної власності : постанова Кабінету Міністрів України від 14.04.2004 № 467. URL: http://zakon2.rada. gov.ua/laws/show/467-2004-\%D0\%BF.

7. Про затвердження методики проведення інвентаризації об'єктів державної власності : постанова Кабінету Міністрів України від 30.11.2005 № 1121. URL: http:// zakon5.rada.gov.ua/laws/show/1121-2005-\%D0\%BF.

8. Щодо запровадження автоматизованої системи «Юридичні особи» в навчальних закладах і установах МОН : наказ Міністерства освіти і науки України від 19.01.2009 № 23. URL: https://mon.gov.ua/ua/npa/shodo-zaprovadzhennya-avtomatizovanoyi-sistemiyuridichni-osobi-v-navchalnih-zakladah-i-ustanovah-mon. 
9. Про затвердження Національного положення (стандарту) бухгалтерського обліку в державному секторі 101 «Подання фінансової звітності» : наказ Міністерства фінансів України від 28.12.2009 № 1541. URL: http://zakon3.rada.gov.ua/laws/show/ z0103-10.

10. Про затвердження Порядку заповнення форм фінансової звітності в державному секторі та Змін до Національного положення (стандарту) бухгалтерського обліку в державному секторі 101 «Подання фінансової звітності» : наказ Міністерства фінансів України від 28.02.2017 № 307. URL: http://zakon0.rada.gov.ua/laws/show/ z0384-17.

11. Про внесення змін до деяких нормативно-правових актів з бухгалтерського обліку в державному секторі : наказ Міністерства фінансів України від 29.11.2017 № 976. URL: http://zakon5.rada.gov.ua/laws/show/z1546-17.

\title{
Valentyna Gapon
}

Ph. D. (Pedagogical), SSI «Institute of Educational Analytics», Kyiv, Ukraine, gapon@mon.gov.ua ORCID ID: https://orcid.org/0000-0001-7521-5450

\section{Olena Barabash}

SSI «Institute of Educational Analytics», Kyiv, Ukraine, o_barabash@mon.gov.ua ORCID ID: https://orcid.org/0000-0003-2545-0369

\section{MONITORING OF INDICATORS OF EQUIPMENT AND MATERIAL PROCUREMENT OF HIGHER EDUCATION INSTITUTIONS}

\begin{abstract}
The authors studied the legal documents on the collection and processing of sectoral reports on the logistics of higher education institutions (HEI). The purpose of the article is to conduct a comparative analysis of the state of logistics of the HEIs of the Ministry of Education and Science of Ukraine using specific statistical and financial indicators. The method of system and structural-hierarchical analysis is applied in the work, it was used to develop the information model of information collection and processing, the methodology and technology of information databases formation; a statistical method for determining the relationships between indicators and developing a system of analytical indicators. For the information and analytical support, the data from the databases «Legal Entities» and «Financial and Economic Reporting» are used, formed using common methodological principles. Analytical indicators make it possible to assess the condition of academic buildings and dormitories, make it possible to identify technically obsolete facilities in need of repair, modernization or decommissioning. To do this, a number of indicators have been calculated and presented, including the provision of space in academic buildings and dormitories per full-time student, the average annual cost of maintaining one square meter of building area, the coefficient of wear and tear, etc. Analytical data are formed based on the financial results of the HEIs for the year 2019 in Ukraine as a whole, for each group of the HEIs and each institution of higher education. The obtained results make possible operational monitoring of the working efficiency of academic buildings and dormitories. The proposed framework of data processing, storage and usage provides high-quality analytical information when making management decisions on logistics issues of the HEIs. The topic of further research should be the development of the information and analytical system combining and using
\end{abstract}


indicators of two information databases, namely «Legal Entities» and «Financial and Economic Reporting».

Keywords: higher education institutions, monitoring, equipment and material procurement, analytical indicators, public real estate, academic buildings, dormitories.

\section{References}

1. Stadnyk, V. V., Yokhna, A. (2011). Strategic management of innovative development of the enterprise. Khmelnytskyi: KhNU [in Ukrainian].

2. Stadnyk, V. V., Sokoliuk, H. O. (2012). Using a balanced scorecard to achieve diversified growth. Bulletin of Khmelnytskyi National University, 4(2), 125-131 [in Ukrainian].

3. Iokhny, M. A. (Ed.). (2007). Concepts of institutional economic theory in managing the development of socio-economic systems. Khmelnytskyi: KhNU [in Ukrainian].

4. Yarmosh, O. V. (2013). System of indicators for monitoring the development strategy of higher education institutions. Topical issues of increasing the competitiveness of the state, business and education in modern economic conditions (pp. 100-102). Dnipropetrovsk: Bila K. O. Retrieved from http://www.confcontact.com/20130214_econ/2013_02_14_econ_ tom2.pdf [in Ukrainian].

5. Verkhovna Rada of Ukraine. (2014). On Higher Education (Act No. 1556-VII, July 1). Retrieved from http://zakon4.rada.gov.ua/laws/show/1556-18/page [in Ukrainian].

6. Cabinet of Ministers of Ukraine. (2004). On approval of the Regulations on the Unified Register of State Property (Decree No. 467, April 14). Retrieved from http://zakon2.rada. gov.ua/laws/show/467-2004-\%D0\%BF [in Ukrainian].

7. Cabinet of Ministers of Ukraine. (2005). About the statement of a technique of carrying out inventory of objects of the state property (Decree No. 1121, November 30). Retrieved from http://zakon5.rada.gov.ua/laws/show/1121-2005-\%D0\%BF [in Ukrainian].

8. Ministry of Education and Science of Ukraine. (2009). Regarding the introduction of the automated system "Legal Entities" in educational institutions and institutions of the Ministry of Education and Science (Order No. 23, January 19). Retrieved from https://mon.gov.ua/ ua/npa/shodo-zaprovadzhennya-avtomatizovanoyi-sistemi-yuridichni-osobi-v-navchalnihzakladah-i-ustanovah-mon [in Ukrainian].

9. Ministry of Finance of Ukraine (2009). On approval of the National Regulation (standard) of accounting in the public sector 101 "Submission of financial statements" (Order No. 1541, December 28). Retrieved from http://zakon3.rada.gov.ua/laws/show/z0103-10 [in Ukrainian].

10. Ministry of Finance of Ukraine (2017). On Approval of the Procedure for Completing Financial Reporting Forms in the Public Sector and Amendments to the National Regulation (Standard) of Accounting in the Public Sector 101 "Submission of Financial Statements" (Order No. 307, February 28). Retrieved from http://zakon0.rada.gov.ua/laws/show/z0384-17 [in Ukrainian].

11. Ministry of Finance of Ukraine (2017). On amendments to some regulations on accounting in the public sector (Order No. 976, November 29). Retrieved from http://zakon5. rada.gov.ua/laws/show/z1546-17 [in Ukrainian]. 